\title{
Corporate Perceptions on Digitalization of Public Services: From the Perspective of Czech SMEs
}

\author{
JIŘÍ STROUHAL \\ Department of Finance and Accounting \\ Škoda Auto University \\ Na Karmeli 1547, 29301 Mladá Boleslav \\ CZECH REPUBLIC \\ JOSEF HORÁK \\ Department of Finance and Accounting \\ Škoda Auto University \\ Na Karmeli 1547, 29301 Mladá Boleslav \\ CZECH REPUBLIC \\ JIŘINA BOKŠOVÁ \\ Department of Finance and Accounting \\ Škoda Auto University \\ Na Karmeli 1547, 29301 Mladá Boleslav \\ CZECH REPUBLIC
}

\begin{abstract}
A frequent shortcoming of the digitalization of public administration and services is an excessive concentration on individual points of communication between the citizen, company and public authorities, rather than focusing on digitalizing the whole process. Digitalizing a service must mean that the entire process from the beginning to the end is digitalized from the end-user's point of view and fully accessible through the online interface. To be able to be competitive in current environment it is necessary that SMEs have easy access to the digitalization processes. The aim of this paper is to provide SMEs point of view on the necessity and applicability of online eGovernmental solutions being vital for their activities. The research was based on surveying of 278 Czech SMEs. We consider the results of this study very topical considering the current COVID19 impact on companies and public administration.
\end{abstract}

Key-Words: - Public services, digitalization, e-government, trade companies, production companies, agricultural companies, service companies, knowledge service companies, Czech Republic

Received: April 23, 2020. Revised: November 28, 2020. Accepted: December 31, 2021. Published: January 14, 2021

\section{Introduction and a Brief Literature Review}

A key prerequisite for the successful digitalization of public administration is to prioritize the target user [1]. The user interface must be intuitive, easy to navigate, and fully integrated across public institutions. This factor often becomes a distinction between successful and unsuccessful digitalization. One of the most common mistakes is the creation of digitalized processes to match and meet public administration needs. Regular collection of information, e.g. through questionnaire surveys and subsequent data analysis, should become a routine procedure at least in the early years since the launch of the digitalized services. All data should be processed in an annual report to identify which areas of digitalization are ranked worst from the end-user perspective and need to be more user-friendly or otherwise optimized.

Another prerequisite for successful digitalization is the comprehensive replacement of current nondigitalized processes with more efficient processes that rely on digital technologies. Unfortunately, it has become a common phenomenon that the digitalization of public administration is associated only with ICT automation of already existing processes in an attempt to convert physical questionnaires and forms to online version [2]. However, this creates a mere digitalization fiction, which externally overlaps existing bureaucratic 
processes. A common problem of even optimally set transformation processes is the reluctance or inability of internal bureaucratic structures to implement changes. If a more complex transformation of processes within public administration and services is about to happen, not just ICT automation of currently applied processes, but investment in the ongoing education of public officials in ICT is a necessary prerequisite.

A frequent shortcoming of the digitalization of public administration and services is an excessive concentration on individual points of communication between the citizen and the authorities, rather than focusing on digitalizing the whole process. Digitalizing a service must mean that the entire process from the beginning to the end is digitalized from the end-user's point of view and fully accessible through the online interface. [3], [4], [5]

The user satisfaction with the digitalized public administration and services decreases significantly when the user is forced to communicate with the authorities at any point in the process, either physically or by telephone.

Similarly, greater emphasis should be put on developing systems / online platforms for digitalized public administration and services that are proactive and not just reactive. In the first phase of successful digitalization, platforms should be created to enable end-users to communicate with authorities easily, intuitively and effectively. The second phase, which is already being developed by some European countries, is to create platforms that are proactive, i.e. initiate communication with natural and legal persons themselves. Recent developments in digitalized services indicate that demand for such interactive platforms will increase significantly in the medium to long term horizon. [6], [7], [8], [9], [10], [11]

According to the trade literature, we can see that the term e-Government is defined in different ways and there is no universally accepted definition of this term. The concept of e-Government is thus an intersection between the public sector, ICT, citizens and companies. Heeks [12] considers that this could be defined as a whole usage of ICT in the public sector. It is possible to work more closely with the concept of using ICT to improve performance in public administration activities. It is expected that eGovernment and digitalization itself have the potential to reduce costs and improve the quality of public services for citizens and companies. We can also see that the digitization of public administration is essential in 2020 thanks to COVID19, which has paralyzed business and public administration activities not only in Asia and then Europe, but truly around the entire world.

\section{Digitalization Issues from SMEs' Perspective}

An essential prerequisite for success is the digitalization of small and medium-sized enterprises, which are the core of the European and Czech economy. The aim of the Czech Republic must therefore be to ensure that SMEs have easy access to the digitalization processes.

Although the Czech Republic has managed to build several successful research centers in recent years, their establishment and development is considerably decentralized and occasionally random. A heterogeneous network of support for research and innovation for many SMEs mean very unequal access to digitalization centers and advice. The Czech Republic must create and build a more structured and systematic form of support for the digitalization of SMEs. Instead of developing an entirely new support network, it would be appropriate to focus on the existing regional innovation centers (innovation centers, technology centers, BIC centers, etc.) and extend their portfolio centrally with digitalization programs. [13], [14], [15], [16]

In addition to consulting, the centers should also promote digitalization through organized workshops and trainings. The aim should also be to involve and interconnect as many local players as possible (public institutions, non-profit sector, chambers of commerce, private sector), because in the case of digital transformation such interconnection becomes an important innovation multiplier.

In particular, the degree of standardization is a key aspect in the digitalization of SMEs. It is precisely the lack of digital standardization templates and the issues of financial return that hinder the digitalization of SMEs. The Czech Republic should therefore follow the German example and create easily transferable estandardization templates for different sectors that are tailored to businesses according to their focus. Only if the individual digitalization processes are interconnected, a fully digitized economy can emerge. In addition, the Czech Republic should set up various platforms for financing or co-financing SMEs in the process of digitalization, according to foreign models. In order to avoid duplication, such projects should then be centrally governed.

The failure of the digitalization process of SMEs is often also a poor perception of the whole process, 
which is defined as a process to increase efficiency, reduce costs or modernize the interface for communication with the target customer. As a result, the potential of digitalization, for example, for the creation of new business models or services that could not exist in practice until then, is ignored. In particular, it is these changes that are most likely to become revolutionary breakthroughs.

Therefore, in an effort to digitalize SMEs, the Czech Republic should not only consider how many Czech SMEs apply digitalization projects, but should also seriously consider what types of digitalization projects are being implemented. Undoubtedly, preference must be given to higherlevel digitalization projects - projects that are more complex and deeper in the operation and overall structure of the company that implements them. In creating incentives for digitalization, the Czech Republic could, for example, apply a method of progressive advantage based on the principle the more complex the digitalization project the individual SME decides to implement, the greater the financial incentive can receive.

The support system for the digitalization of SMEs should provide a more substantial level of support for smaller firms, which have higher financial constraints due to lower turnover. A very similar principle applies undoubtedly to the distinction between the sectors within which SMEs operate. This is true in view of the fact that the financial intensity of the implementation of digitalization projects, in particular, varies considerably across sectors. Therefore, the level of possible financial support must necessarily reflect such a fact.

\section{Research Design}

We carried out a questionnaire survey among SMEs with the aim of identifying which e-Government services they prefer. The survey was realized in November and December 2019 through the phone call interview with the representatives of 278 Czech SMEs. The companies were selected according to their size (based on the number of employees) and the field of activity.

The structure of interviewees was as follows:

Table 1a. Interviewees - sectors

\begin{tabular}{|l|l|l|}
\hline Sector & Number & Structure \\
\hline Production and agriculture & 95 & $34 \%$ \\
\hline Trade & 61 & $22 \%$ \\
\hline $\begin{array}{l}\text { Services and knowledge } \\
\text { services }\end{array}$ & 122 & $44 \%$ \\
\hline
\end{tabular}

\begin{tabular}{|l|l|l|}
\hline Total & 278 & $100 \%$ \\
\hline \multicolumn{3}{|c|}{ Source: own research } \\
\hline
\end{tabular}

Table 1b. Interviewees - respondents

\begin{tabular}{|l|l|l|}
\hline Respondent & Number & Structure \\
\hline CEO & 122 & $44 \%$ \\
\hline CFO & 70 & $25 \%$ \\
\hline ICT manager & 86 & $31 \%$ \\
\hline Total & 278 & $100 \%$ \\
\hline \multicolumn{3}{|c|}{ Source: own research }
\end{tabular}

Respondents were offered a five-point Likert scale of evaluation for the preference of the service (absolutely essential - completely unnecessary). The services as such were divided into two groups: (i) general services, and (ii) finance and HR agenda.

In terms of general services, the survey was focused on the (1A) expansion of open data portal, (2A) online registration of a new company, (3A) consulting and downloads from public registers and the public administration systems, (4A) online change of corporate headquarters in registers, (5A) agenda with company vehicles, (6A) online application for constructions, electronic document circulation, (7A) free online legislation (up-to-date guaranteed by state), (8A) digital electronic identity, (9A) online business support, (10A) online evaluation of corporate partners' creditworthiness, (11A) online claims, (12A) online tracking of bankruptcy proceedings, (13A) online patent and trademarks registration, (14A) online appeals against a decision of the authority or court. Results would be visible from Table 2 .

In terms of finance and HR agenda, the survey was focused on (1B) digitalization of financial statements, (2B) automation of corporate income tax return, (3B) value added tax return, (4B) real estate tax return, (5B) automatic verification of business partner identity, (6B) submission of the information to the national statistical office and to fiscal authorities, (7B) online grant programs submissions, (8B) social and healthcare security agenda, (9B) online solution of distraints, (10B) digital documents, (11B) online testing of digital competences of employees, (12B) automated interconnection with the Labor Office, (13B) online work permits requests for foreign employees. Results would be visible from Table 4 .

\section{Results}

First, we focus on analyzing the results of the first part of the survey focusing on general topics. The highest proportion of responses to the digitalization 
of "very essential" and "very important" were found in the areas of online access to full texts of laws or decrees, as well as extracts from registers and public administration information systems.

For an approximately three-fifths majority, it is essential or very important to allow electronic circulation of documents within the company, online verification of documents (digital electronic identity), online settlement of construction approvals, appeals against decisions of the authority or court, and the matters related to company's vehicles.

On the contrary, digitalization in the area of patent proceedings, online establishment or dissolution of a company or expansion of an open data portal seems to be relatively least essential.

Table 2. Importance of the General eGovernment Services from the Corporate Perspective

\begin{tabular}{|c|c|c|c|c|c|}
\hline Service & oิ & $\begin{array}{l}\vec{\Xi} \\
\text { : } \\
\text { : }\end{array}$ & $\begin{array}{l}\bar{\pi} \\
\stackrel{\bar{E}}{0} \\
\bar{Z}\end{array}$ & 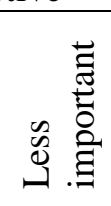 & 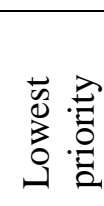 \\
\hline$(3 \mathrm{~A})$ & $29 \%$ & $51 \%$ & $15 \%$ & $4 \%$ & $1 \%$ \\
\hline (7A) & $39 \%$ & $40 \%$ & $15 \%$ & $5 \%$ & $1 \%$ \\
\hline$(8 \mathrm{~A})$ & $22 \%$ & $40 \%$ & $28 \%$ & $9 \%$ & $1 \%$ \\
\hline$(6 \mathrm{~A})$ & $24 \%$ & $37 \%$ & $19 \%$ & $13 \%$ & $7 \%$ \\
\hline$(14 \mathrm{~A})$ & $23 \%$ & $36 \%$ & $27 \%$ & $12 \%$ & $2 \%$ \\
\hline$(5 \mathrm{~A})$ & $17 \%$ & $42 \%$ & $26 \%$ & $11 \%$ & $4 \%$ \\
\hline$(12 \mathrm{~A})$ & $23 \%$ & $35 \%$ & $24 \%$ & $13 \%$ & $5 \%$ \\
\hline$(10 \mathrm{~A})$ & $18 \%$ & $33 \%$ & $25 \%$ & $19 \%$ & $5 \%$ \\
\hline$(4 \mathrm{~A})$ & $18 \%$ & $30 \%$ & $29 \%$ & $19 \%$ & $4 \%$ \\
\hline$(11 \mathrm{~A})$ & $15 \%$ & $30 \%$ & $33 \%$ & $18 \%$ & $4 \%$ \\
\hline$(9 \mathrm{~A})$ & $13 \%$ & $31 \%$ & $35 \%$ & $19 \%$ & $2 \%$ \\
\hline (1A) & $10 \%$ & $29 \%$ & $39 \%$ & $17 \%$ & $5 \%$ \\
\hline (2A) & $10 \%$ & $25 \%$ & $27 \%$ & $25 \%$ & $13 \%$ \\
\hline$(13 \mathrm{~A})$ & $10 \%$ & $21 \%$ & $28 \%$ & $27 \%$ & $14 \%$ \\
\hline
\end{tabular}

Looking at the differences in the evaluation of digitalization in the field of online business depending on the field of activity of the companies surveyed, it is evident that representatives of trade companies are generally more inclined to attach greater importance to the digitalization of assessed areas. Specifically, this means that, in comparison with other companies, trade companies more often consider it important to allow online viewing and extracts from public registers or information systems of public administration, electronic circulation of documents, eventually to change the registered headquarters, or dealing with open data.

The above-mentioned dependency does not apply to digitalization of appeals against the decision of the authority or court, online legislation, company's vehicles, claims proceedings, advisory support, online dissolution of the company, patent proceedings (there are no significant differences between companies according to their field of activity).

Online insolvency proceedings, online administrative proceedings and the evaluation of business partners' creditworthiness are more often described by production and agriculture businesses.

The only area they most often consider to be important service companies is the online complaint procedure.

Table 3. TOP5 Services (Sectoral View)

\begin{tabular}{|l|l|l|l|}
\hline TOP & $\begin{array}{l}\text { Production } \\
\text { and } \\
\text { agriculture }\end{array}$ & $\begin{array}{l}\text { Trade } \\
\text { companies }\end{array}$ & $\begin{array}{l}\text { Services } \\
\text { and } \\
\text { knowledge } \\
\text { services }\end{array}$ \\
\hline 1 & $(7 \mathrm{~A})$ & $(3 \mathrm{~A})$ & $(7 \mathrm{~A})$ \\
\hline 2 & $(3 \mathrm{~A})$ & $(7 \mathrm{~A})$ & $(3 \mathrm{~A})$ \\
\hline 3 & $(12 \mathrm{~A})$ & $(8 \mathrm{~A})$ & $(6 \mathrm{~A})$ \\
\hline 4 & $(8 \mathrm{~A})$ & $(6 \mathrm{~A})$ & $(8 \mathrm{~A})$ \\
\hline 5 & $(14 \mathrm{~A})$ & $(14 \mathrm{~A})$ & $(14 \mathrm{~A})$ \\
\hline
\end{tabular}

Source: own research

In the area of financial and HR agenda, companies most often consider it as essential and very important to digitalize tasks related to health insurance and social security insurance. One third of respondents consider this to be "absolutely essential" and a total of roughly four-fifths of the majority consider it essential or very important. The set of very important areas is further comprised of the tax and accounting areas: automation of value added tax and corporate income tax returns, online translation of information to the fiscal authorities and digitization of financial statements. Equally important for businesses is the automatic verification of business partner identity.

According to the representatives of the company representatives, online confirmation of managerial or other qualifications, online work permits for foreign nationals, free ICT skills trainings or automated connection with the Labor Office can be considered as relatively peripheral areas. 
Source: own research

Table 4. Importance of the Financial and HR Agenda eGovernment Services from the Corporate Perspective

\begin{tabular}{|c|c|c|c|c|c|}
\hline Service & o & $\begin{array}{l}\vec{\Xi} \\
\stackrel{\Xi}{0} \\
\stackrel{\Xi}{\Xi}\end{array}$ & $\begin{array}{l}\bar{\pi} \\
\stackrel{\Xi}{0} \\
\ddot{z}\end{array}$ & 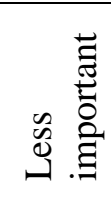 & 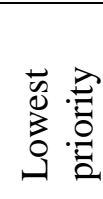 \\
\hline$(8 \mathrm{~B})$ & $32 \%$ & $48 \%$ & $17 \%$ & $2 \%$ & $1 \%$ \\
\hline (3B) & $28 \%$ & $43 \%$ & $19 \%$ & $6 \%$ & $4 \%$ \\
\hline (6B) & $28 \%$ & $43 \%$ & $23 \%$ & $6 \%$ & $0 \%$ \\
\hline (2B) & $26 \%$ & $40 \%$ & $23 \%$ & $8 \%$ & $3 \%$ \\
\hline (1B) & $23 \%$ & $42 \%$ & $30 \%$ & $3 \%$ & $2 \%$ \\
\hline (5B) & $24 \%$ & $41 \%$ & $26 \%$ & $8 \%$ & $1 \%$ \\
\hline (9B) & $23 \%$ & $34 \%$ & $26 \%$ & $14 \%$ & $3 \%$ \\
\hline$(10 \mathrm{~B})$ & $18 \%$ & $38 \%$ & $28 \%$ & $13 \%$ & $3 \%$ \\
\hline (4B) & $19 \%$ & $33 \%$ & $32 \%$ & $11 \%$ & $5 \%$ \\
\hline (7B) & $19 \%$ & $31 \%$ & $28 \%$ & $15 \%$ & $7 \%$ \\
\hline (12B) & $15 \%$ & $27 \%$ & $35 \%$ & $19 \%$ & $4 \%$ \\
\hline (11B) & $9 \%$ & $28 \%$ & $36 \%$ & $21 \%$ & $6 \%$ \\
\hline$(13 \mathrm{~B})$ & $12 \%$ & $24 \%$ & $27 \%$ & $27 \%$ & $10 \%$ \\
\hline
\end{tabular}

The table illustrating the differences in the evaluation of digitalization in the area of financial and HR agenda depending on the field of activity of the surveyed companies confirms the prevailing degree of importance in trade companies. In particular, there is a distinct preference for the digitization of billing documents (e-Invoicing), as well as for the digitalization of financial statements or automatic verification of business partners' identities. On the other hand, it is not so important for trade companies to allow online processing of grants or automated connection with Labour Offices.

More often, companies engaged in agriculture or manufacturing consider it important to deal online with distraint or similar deductions from employees' salaries.

Table 5. TOP5 Services (Sectoral View)

\begin{tabular}{|l|l|l|l|}
\hline TOP & $\begin{array}{l}\text { Production } \\
\text { and } \\
\text { agriculture }\end{array}$ & $\begin{array}{l}\text { Trade } \\
\text { companies }\end{array}$ & $\begin{array}{l}\text { Services } \\
\text { and } \\
\text { knowledge } \\
\text { services }\end{array}$ \\
\hline 1 & $(8 \mathrm{~B})$ & $(8 \mathrm{~B})$ & $(1 \mathrm{~B})$ \\
\hline 2 & $(3 \mathrm{~B})$ & $(3 \mathrm{~B})$ & $(8 \mathrm{~B})$ \\
\hline 3 & $(9 \mathrm{~B})$ & $(6 \mathrm{~B})$ & $(6 \mathrm{~B})$ \\
\hline 4 & $(1 \mathrm{~B})$ & $(1 \mathrm{~B})$ & $(2 \mathrm{~B})$ \\
\hline 5 & $(6 \mathrm{~B})$ & $(5 \mathrm{~B})$ & $(3 \mathrm{~B})$ \\
\hline
\end{tabular}

\section{Conclusion}

The main problem is that companies perceive only partial digitization, when communication between companies and public administration cannot be done without personal or telephone contact, and also confusion and unnecessary difficulty of services.

Based on the results of this research we can say that companies see free access to all legislation and making extracts from public registers and information systems of public administration as top priority. Furthermore, they prefer to digitalize the circulation of documents, digital electronic identity, online settlement of construction approvals, appeal of the company against the decision of the authority or court, handling of the corporate's vehicles and tracking of insolvency proceedings.

In the area of financial and HR agenda, priority is given to digitalizing operations connected with health insurance and social security insurance. Furthermore, it is advisable to automate the agenda related to taxes (VAT, income taxes, real estate tax), digitalize the submission of information to the fiscal authorities and automation of financial statements, and also the automatic verification of the business partners' identity.

The current situation in the context of the global epidemic of COVID19 is a clear demonstration of the need for digitalization at all levels of public administration / government versus company (G2C) to be as maximized as possible in order to minimize not only the administrative burden but also the costs of the relationship flows to both the state and companies. And the fact that fiscal 2020 will hurt state budgets, companies, but also citizens, is more than obvious.

\section{Acknowledgment}

This work was supported in part by the Technology Agency Czech Republic under Program Éta TL01000147.

\section{References:}

[1] C. Dilmegani, B. Korkmaz, and M. Lundqvist, "Public-Sector Digitization: The TrillionDollar Challenge", McKinsey Company, 2014. Available:

https://www.mckinsey.com/businessfunctions/digital-mckinsey/our-insights/publicsector-digitization-the-trillion-dollar-challenge. 
[2] A. DeBenedictis, W. Howell, R. Figueroa, and R. Boggs, "E-Government Defined: An Overview of the Next Big Information Technology Challenge“, Issues in Information Systems, No. 3, 2002, pp. 130-136.

[3] K. Axelsson, and K. Lindblad-Gidlund, "EGovernment in Sweden: New Directions", International Journal of Public Information Systems, Vol. 2009, No. 2, 2009, pp. 31-35.

[4] M. Yildiz, "E-Government Research: Reviewing the Literature, Limitations, and Ways Forward“, Government Information Quarterly, Vol. 24, No. 3, 2007, pp. 646-665.

[5] M. Bokša, J. Bokšová, J. Horák, K. Pavlica, J. Strouhal, and S. Šaroch. "Digital Czech in Digital Europe“, Mladá Boleslav: Škoda Auto University, 2019.

[6] B. Corydon, V. Ganesan, and M. Lundqvist, "Digital by Default: A Guide to Transforming Government ", McKinsey Center for Government, 2016. Available : https://www.mckinsey.com/ media/mckinsey/i ndustries/public\%sector/our\%insights/transfor ming\%government\%20through\%20digitization /digital-by-default-a-guide-to-transforminggovernment.ashx.

[7] European Committee, "Digital "To-Do" List : New Digital Priorities for 2013-2014“, European Commitee press Release, 2012. Available : http://europa.eu/rapid/pressrelease_IP-12-1389_en.htm.

[8] R. Duneja, H. Pichai, A. Lasku, and P. Kilefors, "Digitalization of Government Services, We Want an "Experience" - Not Just Great IT", Arthur D Little, 11/2018. Available: http://www.adlittle.com/sites/default/files/view points/adl_digitalisation_of_government_servic es-min.pdf.

[9] K. Hansteen, J. Olnes, and T. Alvik, "Nordic Digital Identification Survey and Recommendations for Cross Border Cooperation", Norden, 2016. Available: http://Norden.diva-

portal.org/smash/get/diva2:902133/FULLTEX T01.pdf.

[10] H.F. Carapico, "Cyber Security Series: Comparing Best Practice Across Europe", Chatham House, 2019. Available: https:/www.chathamhouse.org/event/cybersecurity-series-comparing-best-practice-acrosseurope.

[11] K. Charlet, "Government in the Crosshairs: Recommendations for Federal Cybersecurity", Carnegies Endowment for International Peace, 2018. https://carnegieendowment.org/2018/04/12/gov ernment-in-crosshairs-recommendations-forfederal-cybersecurity-pub-76022.

[12] R. Heeks, "Implementing and Managing eGovernment: An International Text", London: Sage, 2016.

[13] C. Daheim, J. Korn, and O. Wintermann, "The German Mittelstand and Digital Transformation: Why Change Can Only Succeed with a New Culture of Work", Bertelsmann Stiftung, 2017. Available: https://www.bertelsmann-

stiftung.de/fileadmin/files/BSt/Publikationen/G rauePublikationen/2018_Mittelstand_digital_tr ansformation.pdf.

[14] V. Zimmermann, "Digitalisation in German SMEs: State of Implementation and Investment", KfW, 2018. Available: https:/www.kfw.de/PDF/Download_Center/Ko nzernthemen/Research/PDF-DokumenteFokus-Volkswirtschafts/Fokus-englischeDateien/Fokus-2018-EN/Fokus-NO.-202March-2018-Digitalisation-in GermanSMEs.pdf.

[15] C. Tanner, and S. L. Richter, "Digitalizing B2B Business Processes - The Learnings from EInvoicing", Business Information Systems and Technology, Vol. 141, 2018, pp. 103-116.

[16] E Penttinen, M. Halme, K. Lyytinen, and N. Myllynen, "What Influences Choice of Business-to-Business Connectivity Platforms? “, International Journal of Electronic Commerce, Vol. 22, No. 4, 2018, pp. 479-509.

\section{Creative Commons Attribution License 4.0 (Attribution 4.0 International, CC BY 4.0)}

This article is published under the terms of the Creative Commons Attribution License 4.0

https://creativecommons.org/licenses/by/4.0/deed.en US 